\title{
Effect of applying filter cake and biogas manures on improving some desertic soil properties and their implications on plants grown thereon. II. Implications on plant growth
}

\author{
Mahmoud A. M. Abdelal ${ }^{1}$, Mohamed E. Ali ${ }^{1}$, Esmat H. Noufal ${ }^{1}$ and Ali M. A. El-Nagar ${ }^{2}$

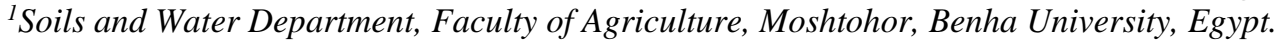 \\ ${ }^{2}$ Soil Department, Faculty of Agriculture, Cairo University, Egypt. \\ Corresponding author: esmat.noufal@yahoo.com
}

\begin{abstract}
The present investigation aims at studying the implications of applying biogas manure and filter cake (Filter mud) as a natural soil amendments on barely plant grown on desertic soils. Two surface soil samples $(0-30$ $\mathrm{cm}$ ) differed in their texture and calcium carbonate content were collected from El-Hammam region, northwestern coast of Egypt. A pot experiment was carried out at the greenhouse of Soils and Water Department, Faculty of Agriculture, Benha University, Egypt, using perforated PVC pots of $5 \mathrm{~kg}$ capacity. Biogas manure and filter cake (filter mud) were added at a rate of 0,1 , and $2 \%(\mathrm{w} / \mathrm{w})$ and thoroughly mixed with the soil and incubated for two months at moisture equivalent to field capacity. Barely plant (Hordum vulgare cv. Giza 123) was used as an indicator plant. Ten grains were planted in each pot. Irrigation was done using tap water so as to reach the water holding capacity of the soil. After complete germination plants were thinned to 5 per pot. Macronutrients; $\mathrm{N}, \mathrm{P}$ and $\mathrm{K}$ were added to all pots according to the rates recommended by the Ministry of Agriculture. The experimental design was factorial randomized complete block design with two factors in three replicates. At maturity, the number of tillers and spikes and plant height were recorded. Plants were harvested and separated into grains and straw and analyzed for $\mathrm{N}, \mathrm{P}$ and $\mathrm{K}$. The obtained results show that:

The number of tillers and of spikes per pot significantly increased with increasing the rate of application of both amendments from R0 up to R2, whereas plant height $(\mathrm{cm})$ significantly and progressively decreased with the rate. Filter cake was more efficient than biogas manure in this respect.

Application of biogas manure and filter cake significantly and progressively increased straw and grain yields in the sandy loam soil (S1), whereas significantly and progressively increased straw yield and decreased grain yield in the loamy sand soil (S2) and there was significant difference between biogas manure and filter cake in this respect. Application of biogas manure and filter cake significantly and progressively increased $\mathrm{N}, \mathrm{P}$ and $\mathrm{K}$ uptake in barley straw with increasing the rate of application and there was significant difference between the two amendments in this respect. Nutrients uptake in barley grains significantly and progressively increased with increasing the rate of the applied amendment except for $\mathrm{N}$ uptake in grains of barley plants grown on the loamy sand soil (S2), where it decreased with increasing the application rate. In the case of the sandy loam soil (S1), biogas manure was more efficient than filter cake in increasing nutrients uptake in barley grains except for $\mathrm{P}$ uptake where filter cake was more efficient than biogas manure in this respect. In the case of the loamy sand soil (S2) biogas manure, also, was more efficient than filter cake in increasing $\mathrm{P}$ and $\mathrm{K}$ uptake in barley grains, whereas, both amendments decreased $\mathrm{N}$ uptake compared with R0 (non application of amendment) and the decrease was higher with the application of filter cake than with the application of the biogas manure. In conclusion the effect of the applied amendments on barley growth parameters, yield and nutrients uptake depends on the chemical properties and the rate of the applied amendment, and the soil characteristics developed upon the application of the organic amendment.
\end{abstract}

Keyword: Biogas manure, filter cake, calcareous soil, sandy soil, physical properties, chemical properties, barley plants.

\section{Introduction}

Land is the major permanent renewable resource and faces the greatest threat of degradation which in turn lead to the desertification of land The United Nations Convention to Combat Desertification (UNCCD, 1994 and Gad and Abdel-Samie, 2000) defined desertification as land degradation in arid, semiarid and dry sub humid areas resulting from climatic variations and anthropogenic activities. Desertification has effect on the soil organic carbon (SOC) (Abubakar and Eniolorunda, 2016). Generally, arid soils have poor quality due to very low levels of soil organic matter (Ravi etal., 2010). Desert reclamation and cultivation is one of the priorities to compensate for the loss of agricultural land in Egypt (Aldabaa et al., 2010).

For the urgent need to meet food and dress demands in Egypt, more desert areas either sandy or calcareous have to be put under cultivation. Such soils are poor with respect to their nutritional status.

Sandy soils are mainly infertile with poor physical chemical properties and require addition of organic manure (Foth, 1990 and Campbell et al., 2002) to improve their fertility. The productivity of sandy soils is mostly limited by their low capacity of retaining 
water and nutrients due to excessive deep percolation losses, which reduce the efficiency of water and fertilizer use by plants. Organic manure increases structural stability and water retention of sandy soils (Nyamangara et al., 2001). Thus, soil conditioners have been recommended to be effective tools for increasing water holding capacity, reducing infiltration rate and cumulative evaporation and improving water conservation of sandy soils. In Egypt, improving sandy soils is considered as an important part of the agricultural security program. Sandy soils represent about $90 \%$ of the Egyptian soils. Such soils represent a great hope for the agriculture expansion.

Calcareous soils cover more than $30 \%$ of the earth's surface and their $\mathrm{CaCO}_{3}$ content varies from a few percent to $95 \%$ (Balba, 1989). Calcareous soils occur naturally in arid and semi-arid zones as well as in humid and semi-humid zones particularly where their parent materials is rich in $\mathrm{CaCO}_{3}$ (Brady, 1990). Organic and mineral soil amendments are soil improving agents. Among the natural soil conditioners, which have been used in Egypt for reclamation of sandy and sandy calcareous soils are organic manures and composts.

Organic and inorganic soil amendments are commonly added to soil for improving its physical and chemical characteristics which promote plant growth. Soil physical and chemical characteristics are affected by soil amendments and production system (Tejada and Gonzalez, 2004 and Aksakal et al., 2012)). Thus, the organic soil amendments are usually mixed with soil to provide the optimal physical and chemical environment to the growing plants (Yangyuoru et al., 2006).
According to El-Banna et al. (2011), barley is the most appropriate choice in Egypt for the risky conditions such as in poor soils and in newly reclaimed areas, which suffer from water shortage and water quality. Barley (Hordeum vulgare L.) is the main crop grown in a large scale in the north coastal region of Egypt and also in the newly reclaimed lands with saline soils and shortage of fresh water. Barley production area increased in the new reclaimed lands under different irrigation systems. Thus, the main objective of the current study was to investigate the implications of applying biogas manure and filter cake as a natural organic amendments to desertic soils differed in their texture and calcium carbonate content on barley plant growth parameters, yield and nutrients and uptake.

\section{Materials and Methods}

A pot experiment was carried out under the greenhouse conditions at soils and water department, Faculty of Agricultural, Benha University during the winter season of 2015-2016 to assess the effect of applying the filter cake and biogas manure, as a natural soil amendments on barley plants grown on desertic soils. Two surface soil samples $(0-30 \mathrm{~cm})$ differed in their texture and calcium carbonate content, were collected from El-Hammam region, north-western coast of Egypt located between latitudes $30^{\circ} 45^{\prime}-31^{\circ} 00^{\prime} \mathrm{N}$ and longitudes $28^{\circ} 30^{\prime} 29^{\circ}$ $00^{\prime} \mathrm{E}$.

The collected soil samples were air dried, crushed and sieved to pass through a $2 \mathrm{~mm}$ sieve. Physical and chemical properties of the studied soils (Table 1) were determined according to the methods cited by Klute (1986) and Page et al. (1982).

Table 1. Physical and chemical properties of the studied soils

\begin{tabular}{|c|c|c|}
\hline Property & Soil 1 & Soil 2 \\
\hline \multicolumn{3}{|c|}{ Particle size distribution } \\
\hline C. Sand (\%) & 27.87 & 30.40 \\
\hline F. Sand (\%) & 37.43 & 48.60 \\
\hline Silt (\%) & 30.65 & 14.00 \\
\hline Clay $(\%)$ & 4.05 & 7.00 \\
\hline Soil texture $*$ & Sandy loam & Loamy sand \\
\hline Saturation percentage $(\%)$ & 47.90 & 30.60 \\
\hline Field capacity (\%) & 24.41 & 5.49 \\
\hline Wilting point $(\%)$ & 2.76 & 0.33 \\
\hline Available water (\%) & 21.65 & 5.16 \\
\hline Bulk density $\left(\mathrm{Mg} \mathrm{m}^{-3}\right)$ & 1.24 & 1.59 \\
\hline Hydraulic conductivity $\left(\mathrm{cm} \mathrm{h}^{-1}\right)$ & 0.99 & 1.11 \\
\hline OM $\left(\mathrm{g} \mathrm{kg}^{-1}\right)$ & 24.81 & 32.12 \\
\hline CEC (cmmolc kg soil-1) & 34.68 & 25.10 \\
\hline $\mathrm{Ca} \mathrm{CO}_{3}\left(\mathrm{~g} \mathrm{~kg}^{-1}\right)$ & 327.00 & 291.00 \\
\hline pH & 7.80 & 7.70 \\
\hline $\mathrm{EC}\left(\mathrm{dS} \mathrm{m}^{-1}\right)$ & 12.70 & 1.00 \\
\hline \multicolumn{3}{|c|}{ Soluble ions $\left(\mathrm{mmol}_{\mathrm{c}} \mathrm{L}^{-1}\right)$ (in Saturated soil paste extract) } \\
\hline $\mathrm{HCO}_{3}^{-}$ & 6.89 & 3.30 \\
\hline $\mathrm{CO}_{3}{ }^{2-}$ & 0.00 & 0.00 \\
\hline
\end{tabular}




\begin{tabular}{lcc}
\hline $\mathbf{C l}^{-}$ & 63.63 & 3.13 \\
\hline $\mathbf{S O}{ }^{2-}$ & 56.16 & 3.85 \\
\hline $\mathbf{C a}^{2+}$ & 36.61 & 5.88 \\
\hline $\mathbf{M g}^{2+}$ & 21.76 & 2.30 \\
\hline $\mathbf{N a}^{+}$ & 65.35 & 1.66 \\
\hline $\mathbf{K}^{+}$ & 2.96 & 0.44 \\
\hline & Available nutrients $\left.\mathbf{( \mathbf { m g ~ k g }} \mathbf{~ g}^{-\mathbf{1}}\right)$ & \\
\hline Available N & 129.5 & 66.5 \\
\hline Available P & 11.26 & 11.90 \\
\hline Available K & 688.00 & 526.00 \\
\hline
\end{tabular}

$\mathrm{pH}$ and EC: were measured in the saturated soil paste extract and $\mathrm{SO}_{4}{ }^{2-}:$ was calculated by the difference between the sum of cations and the sum of anions

* According to international soil texture triangle.

\section{The greenhouse experiment:}

Perforated PVC pots with dimensions of $10 \mathrm{~cm}$ depth and $25 \mathrm{~cm}$ diameter, and a capacity of $5 \mathrm{~kg}$ were used in the current study. Each pot was uniformly packed with $5 \mathrm{~kg}$ of soil. Biogas manure and filter cake and were added at a rate of 0,1 , and $2 \%$ and thoroughly mixed with the soil and incubated for two months at moisture content equivalent to field capacity. Chemical and physical properties of the organic amendments used in the current study are shown in Table 2. Barely plant (Hordum vulgare $\mathbf{c v}$. Giza 123) was used as a test plant. Ten grains were planted in each pot on November $1^{\text {st }} 2015$. Macronutrients, N, P and $\mathrm{K}$ were added to all pots according to the recommended rates of the Egyptian Ministry of Agriculture. Irrigation was done with tap water so as to reach water holding capacity of the soil (about field capacity). After complete germination plants were thinned to 5 per pot.

Table 2. Chemical and physical properties of the organic amendments used in the current study.

\begin{tabular}{|c|c|c|}
\hline Properties & Biogas manure & Filter cake \\
\hline Moisture content (\%) & 19.1 & 9.65 \\
\hline Bulk density $\left(\mathrm{Mg} \mathrm{m}^{-3}\right)$ & 410.00 & 0.27 \\
\hline pH at (1:10 suspension) & 7.80 & 6.60 \\
\hline EC $\left(\mathrm{dS} \mathrm{m}^{-1}\right)$ at $(1: 10$ suspension $)$ & 5.50 & 4.30 \\
\hline $\mathrm{CaCO}_{3}\left(\mathrm{~g} \mathrm{~kg}^{-1}\right)$ & 80.00 & 115.00 \\
\hline CEC (mmolc kg-1 $)$ & 155.94 & 451.39 \\
\hline Organic carbon $\left(\mathrm{g} \mathrm{kg}^{-1}\right)$ & 28.29 & 17.67 \\
\hline Organic matter $\left(\mathrm{g} \mathrm{kg}^{-1}\right)$ & 49.00 & 30.39 \\
\hline Total nitrogen $\left(\mathrm{g} \mathrm{kg}^{-1}\right)$ & 1.90 & 2.8 \\
\hline C: $\mathbf{N}$ ratio & $15: 1$ & $6.31: 1$ \\
\hline Total P $\left(\mathrm{g} \mathrm{kg}^{-1}\right)$ & 11.50 & 18.40 \\
\hline Total K $\left(\mathrm{g} \mathrm{kg}^{-1}\right)$ & 8.00 & 10.50 \\
\hline
\end{tabular}

*Filter cake or mud is one of the waste materials available from the industries of sugar can, composted and used as natural organic amendment.

\section{Fertilization:}

$\mathrm{N}$ was added at $200 \mathrm{mg} \mathrm{N} \mathrm{kg}^{-1}$, while $\mathrm{P}$ and $\mathrm{K}$ were added at 15 and $50 \mathrm{mg} \mathrm{kg}^{-1}$, respectively. Fertilizer sources were ammonium sulphate, calcium superphosphate and potassium sulphate. $\mathrm{N}$ was added in 3 doses (20\% at sowing, $40 \%$ with the first irrigation and $40 \%$ with the second irrigation), while $\mathrm{P}$ and $\mathrm{K}$ were added during soil preparation, immediately before seeding.

The experimental design was factorial randomized complete block design with two factors in three replicates as follows:

Factor A : Organic amendment $(\mathrm{O})$, two organic amendments as follows:

(i) Biogas manure $\left(\mathbf{O}_{1}\right)$

(ii) Filter cake (Filter mud) $\left(\mathbf{O}_{2}\right)$.
Factor B: Rate of application ( $\mathbf{R}$ ), three rates as follows:

i. $\quad \mathbf{R}_{\mathbf{0}}$ : No application of amendment

ii. $\quad \mathbf{R}_{1} 1 \%$ organic amendment (w/w)

iii. $\quad \mathbf{R}_{\mathbf{2}} 2 \%$ organic amendment (w/w)

At maturity, plant height, the number of tillers and spikes were recorded, then, plants were harvested and separated into grains and straw, oven dried at $70{ }^{\circ} \mathrm{C}$ for 24 hours and the dry weight was recorded.

\section{Plant analysis:}

Plant materials were dried at $70{ }^{\circ} \mathrm{C}$ for 24 hours then samples ( 0.5 gram) were ground and wet digested by a concentrated $\mathrm{H}_{2} \mathrm{SO}_{4}$ and $\mathrm{HClO}_{4}$ mixture, and diluted to $100 \mathrm{ml}$ volume. Digests were subjected to $\mathrm{N}, \mathrm{P}$ and $\mathrm{K}$ determination. $\mathrm{N}$ by the Kyldahel method, 
$\mathrm{K}$ by flame photometer and $\mathrm{P}$ by the colormetric method (Murphy and Riley, 1962) modified by He and Honeycutt (2005).

\section{Results and discussion}

\section{Effect on growth parameters:}

Results in Tables 3a, $3 b$ and $3 c$ show the effect of application of the studied organic amendments on barley plant growth parameters.

The main effect of the rate (Table $3 a, 3 b$ and $3 \mathrm{c}$ ) show that application of organic manure and filter cake significantly increased the number of tillers and the number of spikes per pot with increasing the rate of application from $\mathrm{R} 0$ up to $\mathrm{R} 2$, whereas significantly decreased plant height $(\mathrm{cm})$. The decrease in plant height could be attributed to the increase in soil salinity upon the application of the studied amendments. This pattern of response occurred in both of the two studied soils.

The main effect of the organic amendment show that filter cake was significantly more efficient than the biogas manure in increasing the number of tillers and the number of spikes and resulted in higher plant height compared with biogas manure in the two soils.
The higher efficiency of filter cake, in increasing the growth parameters of barely plants could be attributed to its high content of nutrients compared with the biogas manure.

There was an interaction effect between the kind of the organic amendment and the rate of application on the number of tillers, number of spikes and plant height. In the case of number of tillers, application of filter cake to the sandy loam soil (S1) resulted in number of tillers at R1 and R2 higher than that obtained due to the application of biogas manure at the same rates whereas, application of filter cake to the loamy sand soil (S2) resulted in number of tillers at R1 higher than that obtained with the application of biogas manure. At R2 of application the biogas manure was more efficient than filter cake in increasing the number of tillers. Concerning the interaction effect on the number of spikes and plant height, results show that application of biogas manure to the sandy loam soil (S1) gave number of spikes at $\mathrm{R} 1$ equal to that obtained at R2 and the lowest plant height at R2 of application, whereas, application of filter cake to the same soil gave the highest number of spikes and the lowest plant height at R2 of application.

Table 3. Effect of application of biogas manure and filter cake as a natural organic amendments on some growth parameters of barley plants grown on a desertic soils.

a: Numbers of tillers.

\begin{tabular}{|c|c|c|c|c|c|c|c|c|}
\hline \multirow{4}{*}{$\begin{array}{c}\text { Organic } \\
\text { amendment }(O)\end{array}$} & \multicolumn{8}{|c|}{ No. of tillers } \\
\hline & \multicolumn{4}{|c|}{ Soil (1) } & \multicolumn{4}{|c|}{ Soil (2) } \\
\hline & \multicolumn{8}{|c|}{ Rates of addition ( $R$ ) } \\
\hline & $\mathbf{R}_{\mathbf{0}}$ & $\mathbf{R}_{1}$ & $\mathbf{R}_{2}$ & Mean & $\mathbf{R}_{\mathbf{0}}$ & $\mathbf{R}_{1}$ & $\mathbf{R}_{2}$ & Mean \\
\hline $\mathbf{O}_{1}$ & 7.00 & 13.00 & 15.00 & 11.66 & 5.33 & 8.67 & 11.33 & 8.44 \\
\hline $\mathrm{O}_{2}$ & 7.00 & 15.67 & 19.00 & 13.89 & 5.33 & 10.67 & 10.00 & 8.67 \\
\hline Mean & 7.00 & 14.34 & 17.00 & & 5.33 & 9.67 & 10.66 & \\
\hline LSD at $5 \%$ & $\mathrm{O}=0.17$ & $\mathbf{R}=\mathbf{0 . 2 1}$ & $O \times R=1.4$ & & $O=0.18$ & $R=0.71$ & $\mathbf{O} \times \mathbf{R}$ & $=0.41$ \\
\hline
\end{tabular}

b: Number of spikes

\begin{tabular}{|c|c|c|c|c|c|c|c|c|}
\hline \multirow{4}{*}{$\begin{array}{c}\text { Organic } \\
\text { amendment }(O)\end{array}$} & \multicolumn{8}{|c|}{ Number of spikes } \\
\hline & \multicolumn{4}{|c|}{ Soil (1) } & \multicolumn{4}{|c|}{ Soil (2) } \\
\hline & \multicolumn{8}{|c|}{ Rates of addition ( $\mathrm{R}$ ) } \\
\hline & $\mathbf{R}_{\mathbf{0}}$ & $\mathbf{R}_{1}$ & $\mathbf{R}_{2}$ & Mean & $\mathbf{R}_{\mathbf{0}}$ & $\mathbf{R}_{1}$ & $\mathbf{R}_{\mathbf{2}}$ & Mean \\
\hline $\mathbf{O}_{1}$ & 5.33 & 6.67 & 9.00 & 7.00 & 4.67 & 6.00 & 6.33 & 5.67 \\
\hline $\mathbf{O}_{2}$ & 5.33 & 9.67 & 9.67 & 8.22 & 4.67 & 6.33 & 7.00 & 6.00 \\
\hline Mean & 5.33 & 8.17 & 9.33 & & 4.67 & 6.02 & 6.67 & \\
\hline LSD at $5 \%$ & $\mathrm{O}=0.12$ & $\mathbf{R}=\mathbf{0 . 1 5}$ & $\mathbf{O x R}$ & & $\mathrm{O}=0.13$ & $\mathbf{R}=\mathbf{0 . 2 9}$ & $\mathbf{O} \times \mathbf{F}$ & \\
\hline
\end{tabular}

c: Plant height

\begin{tabular}{|c|c|c|c|c|c|c|c|c|}
\hline \multirow{4}{*}{$\begin{array}{c}\text { Organic } \\
\text { amendment }(O)\end{array}$} & \multicolumn{8}{|c|}{ Plant height $(\mathrm{cm})$} \\
\hline & \multicolumn{4}{|c|}{ Soil (1) } & \multicolumn{4}{|c|}{ Soil (2) } \\
\hline & \multicolumn{8}{|c|}{ Rates of addition ( $R$ ) } \\
\hline & $\mathbf{R}_{\mathbf{0}}$ & $\mathbf{R}_{1}$ & $\mathbf{R}_{2}$ & Mean & $\mathbf{R}_{\mathbf{0}}$ & $\mathbf{R}_{1}$ & $\mathbf{R}_{\mathbf{2}}$ & Mean \\
\hline $\mathbf{O}_{1}$ & 56.00 & 48.00 & 47.67 & 50.56 & 57.33 & 53.67 & 49.33 & 53.44 \\
\hline $\mathrm{O}_{2}$ & 56.00 & 51.00 & 46.67 & 51.22 & 57.33 & 51.33 & 52.67 & 53.78 \\
\hline Mean & 56.00 & 49.50 & 47.17 & & 57.33 & 52.50 & 51.00 & \\
\hline LSD at $5 \%$ & $\mathrm{O}=0.42$ & $\mathbf{R}=\mathbf{0 . 5 2}$ & $\mathbf{O} \times \mathbf{R}$ & $=0.89$ & $\mathbf{O}=0.3$ & D $\quad \mathbf{R}=$ & $010 \mathrm{x}$ & $=0.90$ \\
\hline
\end{tabular}


Effect on barely plant yield:

Results in Tables $4 \mathrm{a}$ and $4 \mathrm{~b}$ show the effect of application of biogas manure and filter cake at increasing rate on straw and grain yields of barley plants grown on the studied soils. The main effect of the rate of application show that application of biogas manure and filter cake to the two studied soils significantly increased straw and grain yields in the sandy loam soil (S1) whereas significantly increased straw yield and decreased grain yield in the loamy sand soil (S2). The increase in the straw yield could be attributed to the increase in plant height which would be reflected on the straw yield.

The main effect of the applied organic amendments show that there was significant difference between biogas manure and filter cake in increasing straw and grain yields in the studied soils. In the sandy loam soil (S1), filter cake gave straw yield higher than that obtained due to the application of biogas manure, and visa versa occurred with the grain yield. In case of the loamy sand soil (S2), application of biogas manure gave straw and grain yields higher than those obtained due to the application of filter cake.

There was an interaction effect between the kind of amendment and the rate of application on the straw and grain yields in both of the studied soils. In the sandy loam soil (S1), application of filter cake gave the highest straw yield at R2 whereas gave the highest grain yield at R1, and visa versa occurred with the application of biogas manure. In the case of the loamy sand soil (S2) application of biogas manure gave the highest straw and grain yields at R1. On the other hand, application of filter cake gave the highest straw yield at R1 and the highest grain yield at R2 of application. The decrease in grain yield due to the application of both amendments at increased rate, compared with R0 (no application of amendments) could be attributed to the increase in soil salinity upon their application.

Table 4. Effect of application of biogas manure and filter cake as a natural organic amendments on the straw and a : Straw yield grain yields $\left(\mathrm{g} \mathrm{Pot}^{-1}\right)$ of barley plants grown on a desertic soils.

\begin{tabular}{|c|c|c|c|c|c|c|c|c|}
\hline \multirow{4}{*}{$\begin{array}{c}\text { Organic } \\
\text { amendment }(O)\end{array}$} & \multicolumn{8}{|c|}{ Straw yield $\left(\mathrm{g} \mathrm{Pot}^{-1}\right)$} \\
\hline & \multicolumn{4}{|c|}{ Soil (1) } & \multicolumn{4}{|c|}{ Soil (2) } \\
\hline & \multicolumn{8}{|c|}{ Rates of addition ( $R$ ) } \\
\hline & $\mathbf{R}_{\mathbf{0}}$ & $\mathbf{R}_{1}$ & $\mathbf{R}_{2}$ & Mean & $\mathbf{R}_{\mathbf{0}}$ & $\mathbf{R}_{1}$ & $\mathbf{R}_{2}$ & Mean \\
\hline $\mathbf{O}_{1}$ & 10.60 & 15.17 & 15.03 & 13.60 & 10.68 & 12.13 & 11.17 & 11.32 \\
\hline $\mathrm{O}_{2}$ & 10.60 & 15.00 & 17.57 & 14.39 & 10.68 & 11.36 & 11.22 & 11.09 \\
\hline Mean & 10.60 & 15.08 & 16.30 & & 10.68 & 11.75 & 11.19 & \\
\hline LSD at $5 \%$ & $\mathrm{O}=0.30$ & $\mathbf{R}=\mathbf{0 . 3 7}$ & $\mathbf{O} \times \mathbf{R}=$ & & $\mathrm{O}=0.22$ & $R=0.34$ & $\mathbf{O} \times \mathbf{R}$ & \\
\hline
\end{tabular}

b. Grain yield

\begin{tabular}{|c|c|c|c|c|c|c|c|c|}
\hline \multirow{4}{*}{$\begin{array}{c}\text { Organic amendment } \\
(\text { (O) }\end{array}$} & \multicolumn{8}{|c|}{ Grain yield $\left(\mathrm{g} \mathrm{Pot}^{-1}\right)$} \\
\hline & \multicolumn{4}{|c|}{ Soil (1) } & \multicolumn{4}{|c|}{ Soil (2) } \\
\hline & \multicolumn{8}{|c|}{ Rates of addition ( $R$ ) } \\
\hline & $\mathbf{R}_{\mathbf{0}}$ & $\mathbf{R}_{1}$ & $\mathbf{R}_{2}$ & Mean & $\mathbf{R}_{\mathbf{0}}$ & $\mathbf{R}_{1}$ & $\mathbf{R}_{2}$ & Mean \\
\hline $\mathbf{O}_{1}$ & 7.81 & 10.48 & 11.59 & 9.96 & 10.05 & 9.84 & 9.07 & 9.65 \\
\hline $\mathbf{O}_{2}$ & 7.81 & 10.00 & 9.39 & 9.25 & 10.05 & 8.83 & 9.79 & 9.56 \\
\hline Mean & 7.81 & 10.24 & 10.76 & & 10.05 & 9.33 & 9.43 & \\
\hline LSD at $5 \%$ & $\mathrm{O}=0.3$ & $\mathbf{R}=\mathbf{0 . 3 7}$ & $\mathbf{O} \times \mathbf{R}=$ & & $\mathbf{O}=\mathbf{n . s}$ & $\mathbf{R}=\mathbf{0 . 5 7}$ & $\mathbf{O} \times \mathbf{R}$ & $=0.59$ \\
\hline
\end{tabular}

\section{Effect on nutrients (N, P and K) uptake by barley plants:}

1. Effect on nutrients uptake in straw:

Results in Table 5a, 5b and 5c show the effect of application of biogas manure and filter cake on $\mathrm{N}$, $\mathrm{P}$ and $\mathrm{K}$ uptake in straw of barley plants, respectively.

The main effect of the application rate show that $\mathrm{N}, \mathrm{P}$ and $\mathrm{K}$ uptake in barley straw significantly and progressively increased with increasing the rate of the applied biogas manure and filter cake and the highest increase was obtained due to the application of the studied amendments at R2, except for K uptake where the highest $\mathrm{K}$ uptake occurred with the application of
$\mathrm{R} 1$ in the sandy loam soil ( $\mathrm{S} 1)$ and with $\mathrm{R} 2$ in the loamy sand soil (S2).

The main effect of the kind of amendment show that the highest $\mathrm{N}$ uptake in barley straw was obtained with the application of filter cake to both soils under study, whereas the highest $\mathrm{P}$ and $\mathrm{K}$ uptake was obtained with the application of biogas manure to both soils. The highest $\mathrm{N}$ uptake in barley straw due to the application of filter cake could be attributed to its high content of $\mathrm{N}$ compared with the biogas manure, while the lowest $\mathrm{P}$ uptake in barley straw occurred due to the application of filter cake could be attributed to its high content of $\mathrm{CaCO}_{3}$ compared with the biogas manure 
which decrease the availability of $\mathrm{P}$ to the growing plants (See Table 2).

There was an interaction effect between the kind of the amendment and its rate of application on nutrients uptake especially with $\mathrm{K}$ uptake where the application of biogas manure gave the highest $\mathrm{K}$ uptake in the straw of barley plants grown on the sandy loam soil (S1) at R1 application, whereas, application of filter cake to the same soil gave the highest $\mathrm{K}$ uptake at $\mathrm{R} 2$ of application and visa versa occurred in the loamy sand soil (S2).

Table 5. Effect of application of biogas manure and filter cake as a natural organic amendments on the nutrients uptake by barley straw (mg Pot $^{-1}$ ) of a desertic soils.

a: N-uptake

\begin{tabular}{|c|c|c|c|c|c|c|c|c|}
\hline \multirow{4}{*}{$\begin{array}{c}\text { Organic } \\
\text { amendment }(O)\end{array}$} & \multicolumn{8}{|c|}{ N- uptake (mg Pot $\left.{ }^{-1}\right)$} \\
\hline & \multicolumn{4}{|c|}{ Soil (1) } & \multicolumn{4}{|c|}{ Soil (2) } \\
\hline & \multicolumn{8}{|c|}{ Rates of addition $(\mathbf{R})$} \\
\hline & $\mathbf{R}_{\mathbf{0}}$ & $\mathbf{R}_{1}$ & $\mathbf{R}_{2}$ & Mean & $\mathbf{R}_{\mathbf{0}}$ & $\mathbf{R}_{1}$ & $\mathbf{R}_{2}$ & Mean \\
\hline O1 & 122.83 & 206.13 & 222.90 & 183.75 & 81.53 & 96.30 & 139.75 & 105.86 \\
\hline $\mathbf{O 2}$ & 122.83 & 176.78 & 347.08 & 215.56 & 81.53 & 82.16 & 188.75 & 117.48 \\
\hline Mean & 122.83 & 191.46 & 284.69 & & 81.53 & 89.23 & 164.24 & \\
\hline LSD at $5 \%$ & $\mathbf{O}=7.87$ & $\mathbf{R}=9.62$ & $\mathbf{O} \times \mathbf{R}=$ & & $\mathbf{O}=\mathrm{n} . \mathrm{s}$ & $R=15.16$ & $\mathbf{O} \times \mathbf{R}=$ & .41 \\
\hline
\end{tabular}

See footnotes of Table $3 \mathrm{a}$.

b: P-uptake

\begin{tabular}{|c|c|c|c|c|c|c|c|c|}
\hline \multirow{4}{*}{$\begin{array}{c}\text { Organic } \\
\text { amendment }(\mathbf{O})\end{array}$} & \multicolumn{8}{|c|}{ P- uptake (mg Pot $\left.{ }^{-1}\right)$} \\
\hline & \multicolumn{4}{|c|}{ Soil (1) } & \multicolumn{4}{|c|}{ Soil (2) } \\
\hline & \multicolumn{8}{|c|}{ Rates of addition ( $R$ ) } \\
\hline & $\mathbf{R}_{\mathbf{0}}$ & $\mathbf{R}_{1}$ & $\mathbf{R}_{2}$ & Mean & $\mathbf{R}_{\mathbf{0}}$ & $\mathbf{R}_{1}$ & $\mathbf{R}_{2}$ & Mean \\
\hline 01 & 16.11 & 47.42 & 45.58 & 36.39 & 24.20 & 31.59 & 32.95 & 29.58 \\
\hline $\mathbf{O 2}$ & 16.11 & 31.48 & 51.39 & 32.99 & 24.20 & 28.94 & 31.66 & 28.27 \\
\hline Mean & 16.11 & 39.45 & 48.48 & & 24.20 & 30.27 & 32.30 & \\
\hline LSD at $5 \%$ & $O=2.07$ & $R=2.52$ & $\mathbf{O} \times \mathbf{R}=$ & & $\mathbf{O}=0.82$ & $\mathbf{R}=1.01$ & $\mathbf{O} \times \mathbf{R}=$ & \\
\hline
\end{tabular}

See footnotes of Table 3a.

c: K-uptake

\begin{tabular}{|c|c|c|c|c|c|c|c|c|}
\hline \multirow{4}{*}{$\begin{array}{c}\text { Organic } \\
\text { amendment } \\
(\mathrm{O})\end{array}$} & \multicolumn{8}{|c|}{ K- uptake (mg Pot $\left.{ }^{-1}\right)$} \\
\hline & \multicolumn{4}{|c|}{ Soil (1) } & \multicolumn{4}{|c|}{ Soil (2) } \\
\hline & \multicolumn{8}{|c|}{ Rates of addition ( $R$ ) } \\
\hline & $\mathbf{R}_{\mathbf{0}}$ & $\mathbf{R}_{1}$ & $\mathbf{R}_{2}$ & Mean & $\mathbf{R}_{\mathbf{0}}$ & $\mathbf{R}_{1}$ & $\mathbf{R}_{2}$ & Mean \\
\hline O1 & 128.67 & 742.77 & 648.76 & 506.73 & 311.48 & 334.93 & 423.89 & 356.77 \\
\hline $\mathbf{O 2}$ & 128.67 & 464.30 & 516.86 & 369.94 & 311.48 & 387.15 & 368.20 & 355.61 \\
\hline Mean & 128.67 & 603.53 & 582.81 & & 311.48 & 361.04 & 396.04 & \\
\hline LSD at $5 \%$ & $\mathbf{O}=49.87$ & $\mathbf{R}=61.08$ & $\mathbf{O} \times \mathbf{R}=8$ & & $\mathbf{O}=\mathbf{n . s}$ & $\mathbf{R}=27.30$ & $\mathbf{O} \times \mathbf{R}=$ & 61 \\
\hline
\end{tabular}

See footnotes of Table 3a.

\section{Effect on nutrients uptake in grains:}

Results in Tables 6a, 6b and 6c show the effect of application of the studied organic amendments on nutrients uptake; i.e $\mathrm{N}, \mathrm{P}$ and $\mathrm{K}$ in grains of barley plants grown on the soils under study.

The main effect of the rate of the applied amendments show that nutrients uptake in barley grains significantly and progressively increased with increasing the rate of the applied amendment except for $\mathrm{N}$ uptake in grains of barley plants grown on the loamy sand soil (S2), as it decreased with increasing the application rate. This decrease could be attributed to the obtained low grain yield. However, the decrease was significant only at R2 of application. The highest $\mathrm{N}$ uptake was obtained with the application of R2 to the sandy loam soil (S1) while the highest $\mathrm{P}$ uptake was obtained with the application of R2 to the loamy sand soil (S2), whereas the highest $\mathrm{K}$ uptake occurred with the application of R1 to the sandy loam soil (S1).

The main effect of the applied amendment show that, in case of the sandy loam soil (S1), there were significant differences in nutrients uptake due to the application of biogas manure where it was more efficient than filter cake in increasing nutrients uptake in barley grains except for $\mathrm{P}$ uptake where filter cake was more efficient than biogas manure in this respect. In case of the loamy sand soil (S2), biogas manure also was more efficient than filter cake in increasing $\mathrm{P}$ and $\mathrm{K}$ uptake in barley grains whereas both amendments decreased $\mathrm{N}$ uptake compared with R0 (non application of amendment). 
There was an interaction effect between the kind of the applied organic amendment and its rate of application. In the case of the sandy loam soil (S1) N uptake increased with increasing the application rate of both amendment and the highest $\mathrm{N}$ uptake occurred with the application of biogas manure at the highest (R2), whereas, $\mathrm{P}$ and $\mathrm{K}$ uptake increased with the rate and the highest $\mathrm{P}$ uptake occurred with the application of filter cake at R1, whereas, the highest
$\mathrm{K}$ uptake occurred with the application of biogas manure at R2 of application. In the case of the loamy sand soil (S2), P and K uptake increased with increasing the application rate of the biogas manure and the highest $\mathrm{P}$ and $\mathrm{K}$ uptake was obtained at R2 of application, while application of filter cake increased $\mathrm{P}$ and $\mathrm{K}$ uptake with increasing the application rate and the highest uptake was obtained at R1 and R2, respectively.

Table 6. Effect of application of biogas manure and filter cake as a natural organic amendments on the N-uptake by barley grains $\left(\mathrm{mg}\right.$ Pot $\left.^{-1}\right)$ of a desertic soils.

A: N-uptake

\begin{tabular}{|c|c|c|c|c|c|c|c|c|}
\hline \multirow{4}{*}{$\begin{array}{c}\text { Organic } \\
\text { amendment }(O)\end{array}$} & \multicolumn{8}{|c|}{ N- uptake (mg Pot $\left.{ }^{-1}\right)$} \\
\hline & \multicolumn{4}{|c|}{ Soil (1) } & \multicolumn{4}{|c|}{ Soil (2) } \\
\hline & \multicolumn{8}{|c|}{ Rates of addition ( $R$ ) } \\
\hline & $\mathbf{R}_{\mathbf{0}}$ & $\mathbf{R}_{1}$ & $\mathbf{R}_{2}$ & Mean & $\mathbf{R}_{\mathbf{0}}$ & $\mathbf{R}_{1}$ & $\mathbf{R}_{2}$ & Mean \\
\hline O1 & 34.79 & 64.95 & 102.5 & 67.53 & 43.37 & 40.86 & 29.82 & 38.02 \\
\hline $\mathbf{O 2}$ & 34.79 & 55.66 & 66.81 & 52.42 & 43.37 & 36.63 & 27.97 & 35.99 \\
\hline Mean & 34.79 & 60.30 & 84.83 & & 43.37 & 38.74 & 28.89 & \\
\hline $\begin{array}{l}\text { LSD at 5\% } \\
\text { See footnotes of } \\
\text { :P- uptake }\end{array}$ & $\begin{array}{l}\mathrm{O}=5.19 \\
\text { able 3a. }\end{array}$ & $\mathrm{R}=6.39 \mathrm{O}$ & $\mathrm{R}=9.01$ & & $\mathrm{O}=\mathrm{n} . \mathrm{s}$ & $=6.57 \mathrm{O}$ & $=\mathrm{n} \cdot \mathrm{s}$ & \\
\hline
\end{tabular}

\begin{tabular}{|c|c|c|c|c|c|c|c|c|}
\hline \multirow{4}{*}{$\begin{array}{c}\text { Organic } \\
\text { amendment }(O)\end{array}$} & \multicolumn{8}{|c|}{ P- uptake (mg Pot $\left.{ }^{-1}\right)$} \\
\hline & \multicolumn{4}{|c|}{ Soil (1) } & \multicolumn{4}{|c|}{ Soil (2) } \\
\hline & \multicolumn{8}{|c|}{ Rates of addition ( $R$ ) } \\
\hline & $\mathbf{R}_{\mathbf{0}}$ & $\mathbf{R}_{1}$ & $\mathbf{R}_{2}$ & Mean & $\mathbf{R}_{\mathbf{0}}$ & $\mathbf{R}_{1}$ & $\mathbf{R}_{2}$ & Mean \\
\hline O1 & 2.50 & 6.14 & 7.40 & 5.34 & 5.27 & 7.03 & 11.35 & 7.88 \\
\hline $\mathbf{O 2}$ & 2.50 & 8.41 & 7.35 & 6.10 & 5.27 & 7.62 & 7.50 & 6.80 \\
\hline Mean & 2.50 & 7.27 & 7.37 & & 5.27 & 7.32 & 9.42 & \\
\hline LSD at $5 \%$ & $\mathrm{O}=0.34$ & $\mathrm{R}=0.42$ & O $\times \mathbf{R}$ & & $\mathrm{O}=0.40$ & $\mathbf{R}=\mathbf{0 . 5 0}$ & $\mathbf{O} \times \mathbf{R}$ & \\
\hline
\end{tabular}

c: K-uptake

\begin{tabular}{|c|c|c|c|c|c|c|c|c|}
\hline \multirow{4}{*}{$\begin{array}{c}\text { Organic } \\
\text { amendment } \\
(\mathrm{O})\end{array}$} & \multicolumn{8}{|c|}{ K- uptake (mg Pot $\left.{ }^{-1}\right)$} \\
\hline & \multicolumn{4}{|c|}{ Soil (1) } & \multicolumn{4}{|c|}{ Soil (2) } \\
\hline & \multicolumn{8}{|c|}{ Rates of addition ( $R$ ) } \\
\hline & $\mathbf{R}_{\mathbf{0}}$ & $\mathbf{R}_{1}$ & $\mathbf{R}_{2}$ & Mean & $\mathbf{R}_{\mathbf{0}}$ & $\mathbf{R}_{1}$ & $\mathbf{R}_{2}$ & Mean \\
\hline 01 & 516 & 765 & 825 & 702 & 641 & 730 & 748 & 706 \\
\hline $\mathbf{O 2}$ & 516 & 731 & 641 & 629 & 641 & 612 & 715 & 656 \\
\hline Mean & 516 & 748 & 733 & & 641 & 671 & 732 & \\
\hline LSD at $5 \%$ & $O=16$ & $R=19$ & $\mathbf{O} \times \mathbf{R}=27$ & & $\mathrm{O}=2$ & $\mathbf{R}=\mathbf{2 6}$ & $\mathbf{O} \times \mathbf{R}=37$ & \\
\hline
\end{tabular}

See footnotes of Table $3 a$.

\section{Conclusion}

The effect of the applied organic amendments on barley growth parameters, straw and grain yields and nutrients uptake depends on the chemical properties and the rate of the applied amendment, and the soil characteristics developed upon the application of the organic amendment i.e. the increase in soil salinity, organic matter content, total porosity available nutrient contents and available water content where the effect of these properties was reflected on the growing plants.

\section{References}

Abubakar, S. D., and N. B. Eniolorunda. 2016.

Effect of desertification on some selected soil properties in a semi arid part of Northwestern Nigeria. Journal of Geoscience and Environment Protection, 4: 111-123.

Aksakal, E. L., I. Angin, and T. Oztas. 2012. Effects of diatomite on soil physical properties. Catena, 88: $1-5$.

Aldabaa, A. A., H. Zhang, A. Shata, S. El-Sawey, A. Abdel-Hameed, and J. L. Schroder. 2010. Land sutability classification of desert area in Egypt for some crops using Microleis program. American-Eurasian J. Agric. \&Environ. Sci., 8(1): 80-94.

Ali, W.H. 2013. Suitability of Egyptian deserts for sustainable urban development. Developing Country Studies, 3(8). 
Balba, A., 1989. Management of problem soils in arid ecosystems. Dar El- Matbouat Al- Gadedah, Alex. Egypt.

Brady, N.C. 1990. The Nature and properties of soils, ninth ed. Macmillian Publishing, New York.

Bush, R. 2007. Politics, power and poverty: twenty years of agricultural reform and market liberalisation in Egypt. Third World Quarterly, 28 (8): 1599-1615.

Campbell, D.J., J.V. Stafford, and P.S. Blackwell. 2002. The plastic limit, as determined by the dropcone test, in relation to the mechanical behavior of soil. J. Soil Sci., 31: 11-24.

D'Odorico, P., A. Bhattachan, K.F. Davis, S. Ravi, and C.W. Runyan. 2012. Global desertification: drivers and feedbacks. Advances in Water Resources, 51: 326-344.

Dregne, H.E. 2002. Land degradation in the dry lands. Arid Land Research and Management, 16: 99-132.

EEAA. 2007.. 2007. Egypt Environmental Profile. Egyptian Environmental Affairs Agency (EEAA) [Online] Available: http://www.eeaa.gov.eg/english/main/envprofile .asp

El-Banna, M. N., M. A. Abd El-Gawad, M. N. Mohamed, and M. A. El. Boseely. 2011. Evaluation of 16 barley genotypes under calcareous soil conditions in Egypt. Journal of Agricultural Science, 3 (1): 105-121.

El-Hady, O.A., and S.A. Abou-Sedera. 2006. The conditioning effect of composts (natural) or/and acrylamide hydrogels (synthesized) on a sandy calcareous soil. II. Chemical and biological properties of the soil. Egypt. J.Soil Sci., 43: 538546.

Foth, H.D. 1990. Fundamentals of soil science. 8 Ed. John Wiley and Sons. New York, USA. th 5.

Gad, A., and S. Abdel-Samie. 2000. Study on desertification of irrigated arable lands in Egypt. Egypt. J. Soil Sci., 40 (3): 373-384.

Gray, L.C. 1999. Is land being degraded? A multiscale investigation of landscape change in southern Burkina Faso. Land Degrad. Develop., 10:329-343.

He, Z. and C. W. Honeycutt. 2005. A modified molybdenum blue method for orthophosphate determination suitable for investigating enzymatic hydrolysis of organic phosphates. Soil and plant analysis, 36: $1373-1383$

Klute, M. 1986. Methods soil analysis. Part1. Physical and Mineralogical Methods $2^{\text {nd }}$ Ed. Am.

Misak, R.F., J.M. Al-Awadhi, S.O. Omar, and S.A. Shahid. 2002. Soil degradation in Kabd, Southwestern Kuwait city. Land Degrad. Develop., 13:403-415.

Murphy, J. and I. P. Riely. 1962. A modified single solution method for the determination of phosphate in natural waters. Anal. Chim. Acta. 27: 31-36.

Nyamangara, J., J. Gotosa and S.E. Mpofu. 2001. Cattle manure effects on structural stability and water retention capacity of a granitic sandy soil in Zimbabwe. Soil and Tillage Res., 62: 157-162.

Page, A.L., R. H. Miller and D.R. Keeney 1982. Methods of soil analysis. Part 2: Chemical and Microbiological Properties. Second edition. Agronomy J. 9: 2, Am. Soc. Agron. Inc., Soil Sci. Soc. Am. Inc. Pub. Madison, Wisconsin, USA.

Ravi, S., D.D. Breshears, T.E. Huxman, and D. D'Odorico. 2010. Land degradation in drylands: interactions among hydrologic-aeolian erosion and vegetation dynamics. Geomorphology, 116: 236-245.

Snedicor, G. W. and W. G. Cochran. 1980. Statistical Methods, 6th ed. Iowa State Univ. Press, Iowa, USA.Soc. of Agr., Inc., Soil Sci. Soc. of Am., Inc Madison, Wisconsin, USA., 399 - 404.

Tewari, V.P. and R. Arya. 2005. Degradation of arid rangelands in Thar desert, India: A Review. Arid Land Research and Management, 19: 1-12.

UNCCD. 1994. United Nations convention to combat desertification in countries experiencing serious Drought and/or desertification, Particularly in Africa. A/AC.241/27, Paris. Tejada, M., and J.L. Gonzalez. 2004. Effects of application of a byproduct of the two-step olive oil mill process on maize yield. Agron. J. 96, 692-699.

Watson, C. A., D. Atkinson, P. Gosling, L. R. Jackson, and F. W. Rayns. 2002. Managing soil fertility in organic farming systems. Soil Use Manage., 18: 239-247.

Wessels, K.J., S.D. Prince, and I. Reshef. 2008. Mapping land degradation by comparison of vegetation production to spatially derived estimates of potential production. Journal of Arid Environments, 72: 1940-1949.

Wessels, K.J., S.D. Prince, J. Malherbeb, J. Small, P.E. Frost, and D. VanZyl. 2007. Can humaninduced land degradation be distinguished from the effects of rainfall variability? A Case Study in South Africa. Journal of Arid Environments, 68: 271-297.

Yangyuoru, M., E. Boateng, S.G.K. Adiku, D. Acquah, T.A. Adjadeh, and F. Mawunya, 2006. Effects of natural and synthetic soil conditioners on soil moisture retention and maize yield. West Africa J. Applied Ecol., 9: 1-8.

Yilmaz, E., and Z. Alagöz. 2010. Effects of shortterm amendements of farmyard manure on some soil properties in the Mediterranean region Turkey.

Zia, M.S. 1993. Soil fertility evaluation and management for flooded lowland rice soils of Pakistan. Ph. D. Dissertation, Kyoto University, Japan. 


\title{
تأثير إضافة روث الغاز الحيوى ( سماد البيوجاز) وطينة التصفية على تحسين بعض خواص الاراضى الصحراوية وتداعيتها على النبات النامى عليها.
}

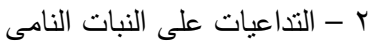

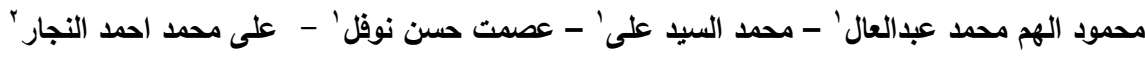

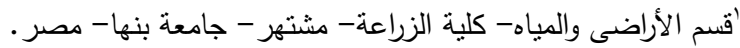

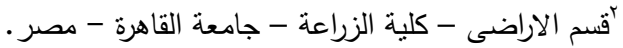

يهدف البحث الحالي إلى دراسة تأثير إضافة روث الغاز الحيوي (Biogas manure) وطينة التصفية Filter cake or filter mud على النباتات المزروعة على أراضى صحراوية. لتحقيق هذا الهدف جُمعت عينتان من الطبقة السطحية (. - .ب سم) لأرضين من منطقة الحمام، الساحل

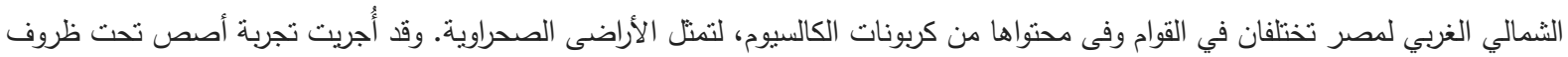

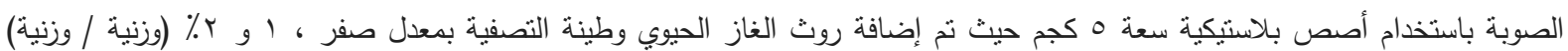

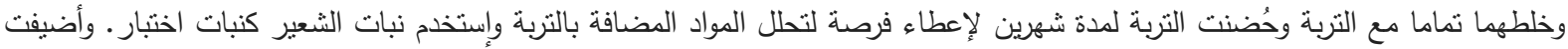

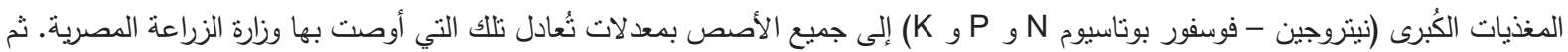
تم زراعة عشرة حبات شعير في كل أصيص وتم الري باستخدام مياه الصنبور حتى الوصول إلى السعة الحقلية للتربة. بعد تمام الإنبات خُّفت

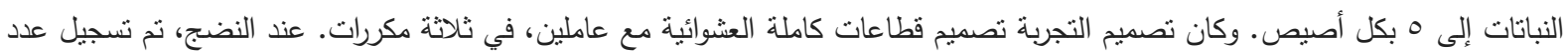

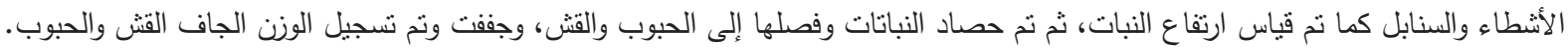

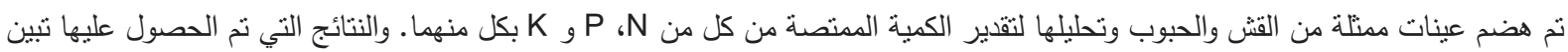
ما يلي:

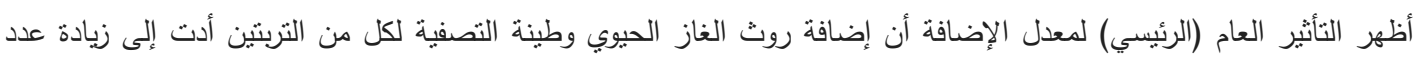

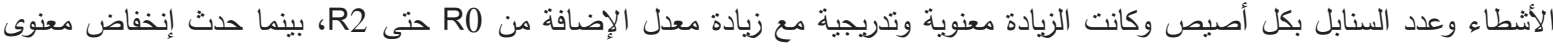

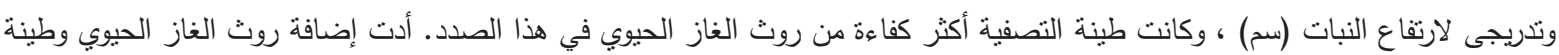

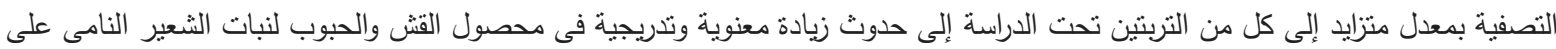

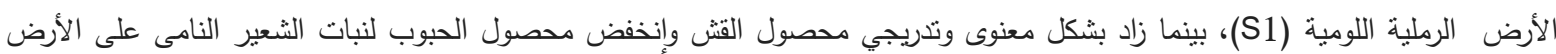
الللومية الرملية (S2) ، وكان هناك فرق معنوى بين روث الغاز الحيوي وطينة التصفية في زيادة محصول القش والحبوب للنباتات الثشعبر المزروعة

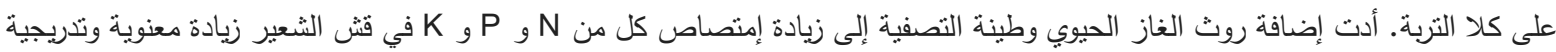

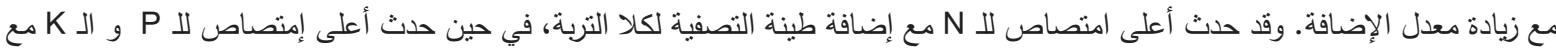

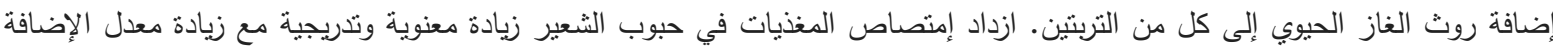
باستثاء النتروجين المنص في حبوب نباتات الثعير المزروعة على التربة اللومية الرملية (S2) حيث إنخفض مع زيادة معدل الاضافة ، وكانت هناك فروق معنوية في امتصاص العناصر الغذائية بسبب إضافة كلا المحسنين إلى الأراضى المدروسة. ففي حالة التربة الرملية اللومية (S1) ،

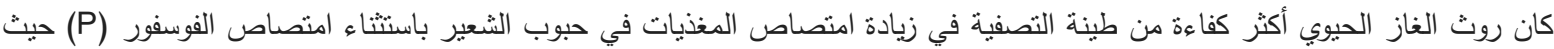

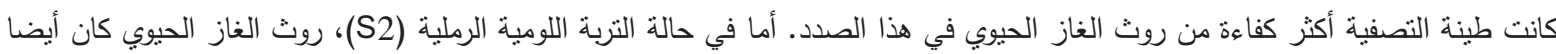
أكثر كفاءة من طينة التصفية في زيادة امتصاص P و T في حبوب الثعبر، في حين أن كلا المحسنين أدوا إلى خفض كمية الـ N الممنصة مقارنة مع R0 (عدم إضافة المحسن) و كان الانخفاض أعلى مع إضافة طينة التصفية مقارنة مع إضافة روث الغاز الحئ الحيوي.

الخاتمة

ويمكن إستتاج أن تأثير المحنات المضافة على مؤشرات نمو نبات الثعبر ، والمحصول، وامتصاص العناصر الغذائية يعتمد على الخواص الكيميائية للمحسن ومعدل إضافتة ، وخصائص التزبة المتطورة نتيجة إضافة المحسن العضوي متل زيادة محتوى التنربة من الأملاح والمادة

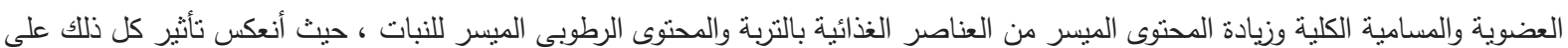

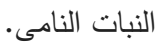


